\title{
高齢者施設のにおい環境と対策に関する全国調査 ODOUR ENVIRONMENT AND MANAGEMENT IN FACILITIES FOR THE ELDERLY
}

\author{
金 勲*1, 阪東 美智子*2, 林 基 哉*3, 大澤 元 毅*1 \\ Hoon KIM, Michiko BANDO, Motoya HAYASHI \\ and Haruki OSAWA
}

\begin{abstract}
Although facilities for the elderly are in high demand, the actual situation of indoor environment has not been clear since there have not been a regulation and control law at all. The mid and long term goal of our research is to suggest the proper planning and operational management to improve the indoor air environment in those facilities, and the field and questionnaire surveys on special nursing homes all over the country have been carried out.

In this study to clarify the odour environment and problems, the questionnaire items related to the odour environment were extracted and analyzed statistically.
\end{abstract}

Keywords : Facility for the elderly, Special nursing home, Odour, Indoor environment, Nationwide survey 高齢者施設，特別養護老人ホーム，におい，室内環境，全国調査

\section{1. はじめに}

日本は 2007 年に超高齢社会が到来して以来 2014 年には高齢化率

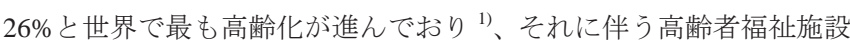
の需要が急増している。入所型社会福祉施設の入所者約 145 万人のう ち 8割以上が 65 歳以上の高齢者であり、今後さらなる高齢化と要介 護度の上昇が想定される。 ${ }^{2)}$ 高齢者施設における室内環境の現状把握 と改善策は喫緊の課題である。3), 4), 5)

一方、高齢者施設における環境衛生の維持管理に対してはその法的 根拠がないため行政からの立ち入りや介入が難しく、実態や対策に関 する全貌は未だに明確になっていない。

入所型高齢者福祉施設は要介護度の高い高齢者が多いため、生活の 面からも様々な介護サービスが必要となり、例えば排泄介助は介護従 事者、入所者、訪問者などに視覚・嗅覚的不快感を与える。嗅覚不快 感はにおいの適切な排出行為が行われなければ拡散により周りへの 影響が大きくなることが想定される。村田、光田らは在宅介護におけ るにおい問題において排泄物、生ゴミ、排水口、体臭などへの不快感 が大きいことを報告し、要介護度との相関を調べている。の，7) また、 発生源及びにおい成分の特定 ${ }^{8}$, 9) や器具設備などで消臭効果について 調べた研究が散見され、最近は病院の換気制御に $\mathrm{CO}_{2}$ 濃度だけでは なくにおいセンサーを利用する試みも報告されている。10) また、高 齢者施設の空気環境と衛生管理に関する実測調査 ${ }^{11)}$, 12) や温湿度・CO2 濃度と換気量推定 ${ }^{13)}$ などの研究結果が報告されている。しかしなが ら、特別養護老人ホームのような大規模入所型施設における建築・施
設・設備全般とにおい環境の実態についての全国調査に関する報告は 見られない。

このような背景から、本研究グループは全国の特別養護老人ホーム (以下、特養) を対象に、施設の室内環境並びに施設設備に関する管 理状況や配慮事項について実態を把握し、高齢者施設の室内環境の適 正な計画と運用管理の提案を行うことを目的とし、実態調查及び現場 実測を行っている。

既報 ${ }^{14)}$, 15)では全国アンケート調查による、特養の施設概要、運営 形態、空調設備の概要、室内環境の管理状況などについて報告した。

本報では、高齢者福祉施設におけるにおい環境の問題と職員の認識 及び対応についての現状を明らかにするために、同アンケート調査か ら関連項目を抽出・分析し、報告する。

\section{2. 研究方法}

本報では、以下に示寸調査項目のうち、におい環境とその対策及び 施設側の認識に関する結果をまとめるとともに、知覚空気質「快不快 度・臭気強度・受容度」と他の設問項目との相関について分析を行っ た。統計分析にはSAS-JMP11 を使用した。なお、複数回答を許して いるため比率の合計が必ずしも100\%にならない場合がある。

\section{1 調査概要}

ホームページ上で無償公開・提供している二次医療圈データ「全国 特別養護老人ホーム一覽データ」 ${ }^{16)}(2011$ 年 4 月現在 $)$ を活用し、2013
*1 国立保健医療科学院生活環境研究部 主任研究官·博士 (工学)

*2 国立保健医療科学院生活環境研究部 上席主任研究官・博士 (工学)

*3 国立保健医療科学院 統括研究官・博士 (工学)
Senior Researcher, National Institute of Public Health, Dr.Eng.

Chief Senior Researcher, National Institute of Public Health, Dr.Eng.

Research Managing Director, National Institute of Public Health, Dr.Eng. 
年 11 月〜12 月に渡って郵送によるアンケート調査を行った。質問対 象は施設管理者や担当者である。有効発送数 5,878 に対し 767 票 (13.0\%) の有効回答を得た注 ${ }^{1)}$ 。調查項目は、所在都道府県、設置・ 運営主体、施設規模、定員、居室概要、利用者数、利用者の特性（要 介護度）、暖房・冷房・換気設備形式、温熱空気環境の管理状況（設 定基準、管理体制）、臭気の状況と対策、感染症の発生状況、温熱空 気環境に関する配慮事項等である。本報では、質問項目の中から、に おい環境及びその対策の現状、換気状況及び換気への認識に関する内 容について抽出・解析した。

分析にあたっては、地域の気候区分による影響をみるため、経済産 業省・国土交通省「エネルギーの使用の合理化に関する建築主等及び 特定建築物の所有者の判断の基準」 ${ }^{177}$ の地域区分を採用した 注2）注3)。

\section{2 知覚空気質}

知覚空気質に関しては、快不快度、臭気強度、そして受容度につい て設問した。快不快度は「極端に不快」から「極端に快」までの 9 段階、臭気強度については「無臭」から「極端に強い」まで 7 段階の 尺度から番号を選んでもらった。受容度に関しては「受け入れられな いーどちらでもない一受け入れられる」から一つを選んでもらった。

\section{Q. 3) Hedonic tone and odour intensity}

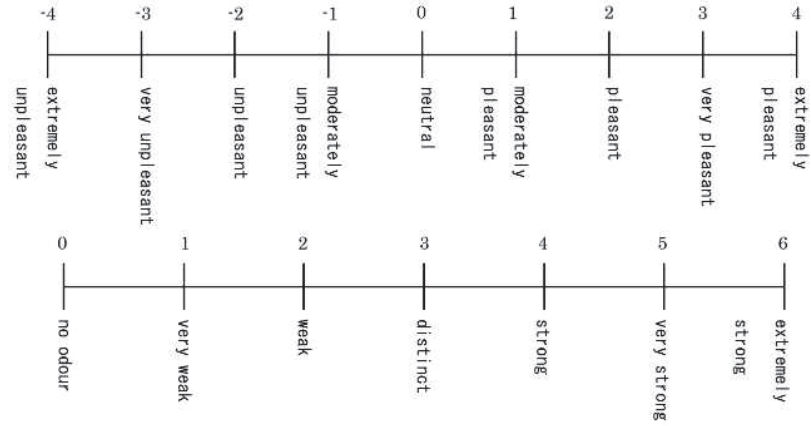

Q. 4) Acceptability

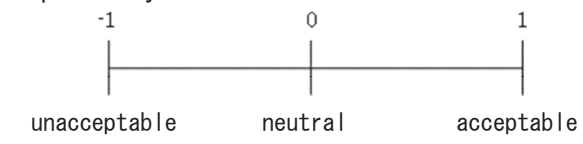

Fig. 1 Questionnaire for odour perception

\section{3 相関分析}

アンケート回答はまず細部設問別に知覚空気質に対する二変量解 析を行い、各項目間の相関を調べた。更に、解析結果から臭気環境と 有意性が認められた因子を抽出して多变量解析を行った。解析には SAS-JMP11 を使用し、有意水準 5\%、相関の判断としてはギルフォー ド基準 (Guilford's Rule of Thumb) 注4) を適用した。但し、延べ床面 積はスケールが大きいため $1000 \mathrm{~m}^{2}$ 未満、1000～3000 m²、3000～5000 $\mathrm{m}^{2} 、 5000 \mathrm{~m}^{2}$ 以上と 4 分類にし、1 から 4 の整数を代表值とした。

\section{3. におい環境に関するアンケート結果}

「(1)においが気になる場所 $(n=762) 」 、 「(2)$ 気になっているにおい は何か $(n=549)$ 」、「(3)知覚空気質（快不快度・臭気強度・受容度 $)$

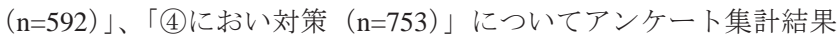
を報告する。(1)、(2)、(4)に関しては複数回答可としているため、比率 の合計が必ずしも $100 \%$ にならない場合がある。

また、調查対象の属性として既報 ${ }^{14), 15)}$ で施設と建築・設備概要、
室内環境の管理状況などについて報告した内容を次に簡単に䌂める。 入所定員は平均 71 人、実際の利用者数 70 人、職員数 47 人、利用者 の要介護度平均は 3.9 と「重度な介護が必要な状態（要介護 4)」にあ る。床面積平均は $3,273 \mathrm{~m}^{2}$ (S.D. 1,576)、平均築年数 18 年 (S.D.9.9) と多くの施設が改修・改築期を迎えており、改修・改築があった場合 その年を基準にすると平均 12.7 年 (S.D.9.2) である。建物構造は約 9 割が鉄筋コンクリート造、平均階数 2.6 であり 3 階建以下の低層が 8 割を占める一方、特養部分の専用フロア数は平均 2.0 (S.D.1.0) であ る。施設形態としては従来型が 6 割以上を占めている中、2000 年以 降に建てられた施設はユニット型化が進んでいるが多床室への需要 は依然と高く、従来型とユニット型を併設している施設も多い。

\section{1 においが気になる場所及び気になるにおいの種類}

Fig.2 に示寸ように、気になる場所が「無い」が 33\%、「居室」45\%、 「廊下」 $22 \%$ 、「共用室」 $14 \%$ 、「その他」が $26 \%$ と居室の割合が最 も高い。「その他」の内訳として、トイレ 56\%、污物処理室 21\%、才 ムッ交換・排泄介助関連が $9 \%$ であった。

気になるにおい（Fig.3）としては、「糞便臭」が 80\%、「尿臭」15\% と糞尿関連で重複を除いて $90 \%$ 以上、「体臭」 $17 \%$ 、「食物臭」 $8 \%$ で あり、大多数の施設で臯便・尿臭が挙げられた。上述したようにトイ レや污物処理室よりも居室、廊下がにおいが気になる場所として挙げ られている。これは要介護度が高く、自力でトイレが利用できる利用 者よりはオムツ交換やポータブルトイレなど排泄介助を受けるしか ない利用者が多いこと、また加齢臭などの体臭が気になっているため

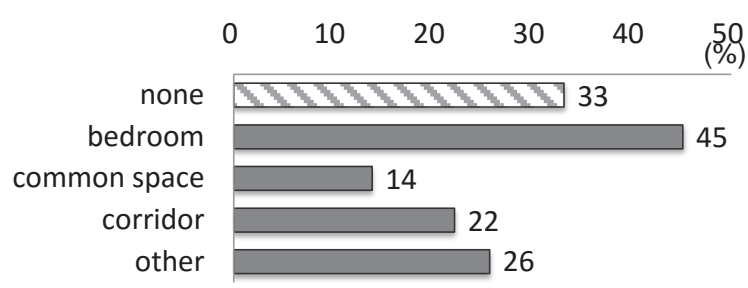

Fig. 2 Odorous places

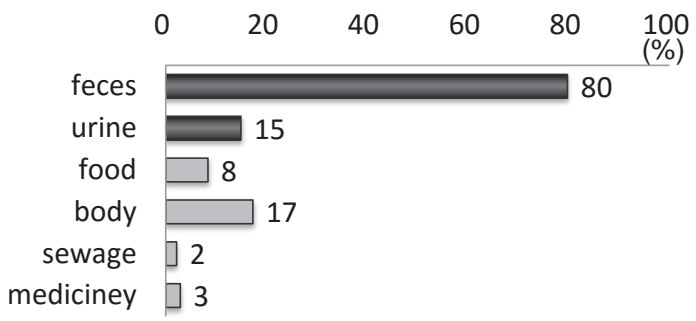

Fig. 3 Unpleasant odours

Table 1 Odorous places and unpleasant odours

\begin{tabular}{c|r|r|r|r|r|r|r|r}
\hline \multicolumn{1}{l|}{ place } & feces & urine & food & body & sewage & $\begin{array}{r}\text { medi- } \\
\text { ciney }\end{array}$ & total \\
\hline $\begin{array}{c}\text { none } \\
(n=253)\end{array}$ & Response quantity & 40 & 5 & 2 & 2 & 0 & 1 & 50 \\
\hline $\begin{array}{c}\text { bedroom } \\
(n=344)\end{array}$ & Response quantity & 282 & 53 & 31 & 84 & 2 & 11 & 463 \\
\hline common & percent (\%) & 82.0 & 15.4 & 9.0 & 24.4 & 0.6 & 3.2 & 134.6 \\
(n=106) & Response quantity & 85 & 13 & 26 & 29 & 0 & 5 & 158 \\
\hline corridor & Rercent (\%) & 80.2 & 12.3 & 24.5 & 27.4 & & 4.7 & 149.1 \\
$(n=169)$ & perponse quantity & 133 & 26 & 27 & 35 & 2 & 8 & 231 \\
\hline toilet & Response quantity & 81 & 17 & 6 & 17 & 3 & 3 & 127 \\
$(n=100)$ & percent (\%) & 81.0 & 17.0 & 6.0 & 17.0 & 3.0 & 3.0 & 127.0 \\
\hline other & Response quantity & 153 & 30 & 9 & 27 & 11 & 7 & 237 \\
$(n=196)$ & percent (\%) & 78.1 & 15.3 & 4.6 & 13.8 & 5.6 & 3.6 & 120.9 \\
\hline
\end{tabular}


と考えられる。「下・排水」「消毒・薬剤臭」はそれぞれ 2\%、3\%程 度と少ない。

Table1 ににおいが気になる場所と気になるにおいの種類を集計し て示した。申告数の下段に示す割合（\%）は該当場所の申告数に対す る百分率である。複数回答が可能であったため気になる場所が「無い」 と答えた施設であっても約 16\%は糞便臭がするとしている。気にな る場所があると申告した回答では、居室・共用室を含めた施設内の殆 どの空間において 8 割程度は糞便臭が、12１7\%は尿臭がすると回答 している。食物臭は共用室と廊下での申告率が高く、体臭は居室・共 用室・廊下共に 2 割以上と利用者が滞在する空間では体臭が問題とな っている。下水と薬剤臭は申告数は少ないが、下水臭は「その他」の 空間で約 $6 \%$ 、薬剤臭は施設内の全空間で3〜4\%の申告があった。

\section{2 におい対策}

Fig.4 ににおい対策を示す。Bed は居室（Bedroom）、ComS は共用 室 (Common Space) である。におい対策として最も多く取り入れら れているのは「換気扇」(約 7 割）で、「芳香・防臭剤」（居室 49\%、 共用室 35\%)、「空気清浄機」（居室 23\%、共用室 31\%)、「オゾン発生 器」（居室 23\%、共用室 28\%）が次いだ。機能性「建材」を施工して いる施設は約 3\%あった。「芳香・防臭剤」は共用室より居室で使用 率が高く、「空気清浄機」及び「オゾン発生器」は共用室での使用率 が高い。また「2 種類以上の対策を取っている」と答えた施設は居室 が 59\%、共用室が 55\%あり、全施設における居室の 37\%、共用室の $34 \%$ で「2 つ以上併用」、「3 つ以上併用」がそれぞれ 18\%ずつ、「4つ 以上併用している」と答えた施設も居室 $4 \%$ 、共用室 3\%あり、にお い低減に苦慮していることがうかがわれた。「対策を取っていない」 と答えた施設は居室・共用室ともに $3 \%$ のみであった。

「その他」も約 1 割程度あり、その内訳としては「空開け換気」が 最も多く、「小まめな掃除」、「消臭スプレーを使う」、「電解水・消臭 効果のある液剂の発生装置を置く」、「口腔ケアの実施」などが次いだ。

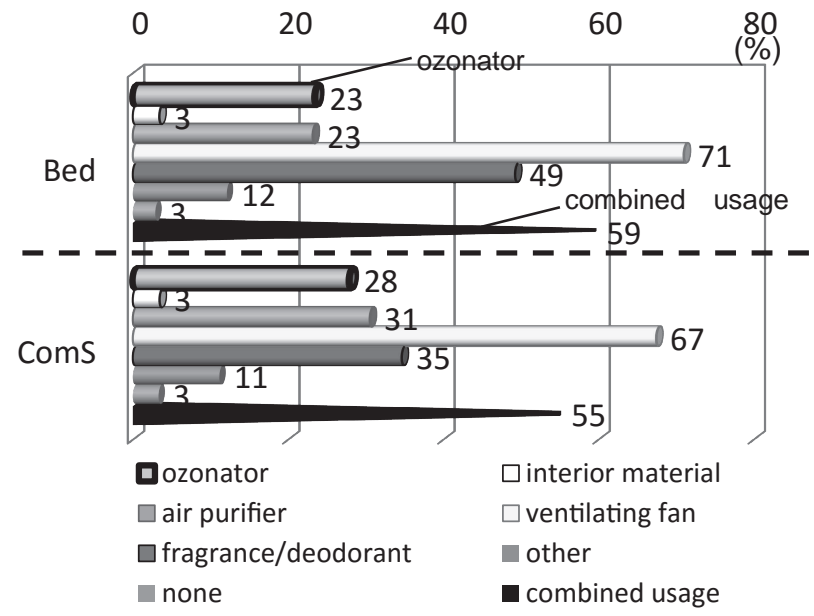

(Bed : bedroom/居室, ComS : common space/共用室)

Fig. 4 Measures for odour control

Table2 ににおい対策として併用している手段の内訳を示す。申告数 の下段に示寸割合 (\%) は居室での併用申告数 $n=450$ 、共用室 $n=412$ に対する百分率である。居室にオゾン発生器を設置している施設では 併用率が換気扇 $(23 \%) 、$ 芳香・防臭剂 $(16 \%)$ 、空気清浄器 $(10 \%)$ となっているが、空気清浄器を設置している場合は換気扇 $(28 \%) 、$

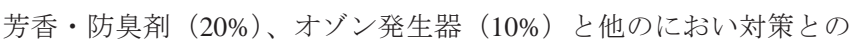

併用率が若干高くなっている。換気扇は対策として取り入れている訳 ではなく建物の必須設備であり、日常的に他の対策と一緒に使われて いると考えられる。一方、オゾン発生器や空気清浄器は費用が掛かる 分、室内空気に関してある程度意識がある施設と考えられ、他の対策 も積極的に取り入れている可能性がある。

居室では芳香・防臭剤の使用が多いが、共用室ではやや低くなる反 面、オゾン発生器や空気清浄器の使用が多くなっていることから、施 設側でも空間特性を考慮したにおい対策を取っていることが分かる。

Table 2 Details of combined usage of odor control measures

\begin{tabular}{|c|c|c|c|c|c|c|c|}
\hline $\begin{array}{r}b \\
\text { (combinec }\end{array}$ & $\begin{array}{l}\text { edroom } \\
d \text { usage }: n=450)\end{array}$ & ozonator & $\begin{array}{l}\text { interior } \\
\text { material }\end{array}$ & $\begin{array}{c}\text { air } \\
\text { purifier }\end{array}$ & $\begin{array}{l}\text { vent } \\
\text { fan }\end{array}$ & \begin{tabular}{r|r} 
fragrance \\
deodorant
\end{tabular} & other \\
\hline & response quantity & & 5 & 45 & 104 & 74 & 6 \\
\hline ozonator & percent $(\%)$ & & 1.1 & 10.0 & 23.1 & 16.4 & 1.3 \\
\hline interior & response quantity & & & 5 & 20 & 13 & 3 \\
\hline material & percent $(\%)$ & & & 1.1 & 4.4 & 2.9 & 0.7 \\
\hline air nurifier & response quantity & & & & 128 & 91 & 13 \\
\hline darr purnter & percent $(\%)$ & & & & 28.4 & 20.2 & 2.9 \\
\hline vent $f$ n & response quantity & & & & & 280 & 60 \\
\hline Vent tan & percent (\%) & & & & & 62.2 & 13.3 \\
\hline $\begin{array}{l}\text { fragrance } \\
\text { deodorant }\end{array}$ & $\begin{array}{r}\text { response quantity } \\
\text { percent }(\%)\end{array}$ & & & & & & $\begin{array}{l}32 \\
7.1\end{array}$ \\
\hline other & $\begin{array}{r}\text { response quantity } \\
\text { percent }(\%)\end{array}$ & & & & & & \\
\hline $\begin{array}{r}\text { com } \\
\text { (combinec }\end{array}$ & $\begin{array}{l}\text { mon space } \\
\text { d usage }: n=412)\end{array}$ & ozonator & $\begin{array}{l}\text { interior } \\
\text { material }\end{array}$ & $\begin{array}{c}\text { air } \\
\text { purifier }\end{array}$ & $\begin{array}{l}\text { vent } \\
\text { fan }\end{array}$ & $\begin{array}{r}\text { fragrance } \\
\text { deodorant }\end{array}$ & other \\
\hline R7onar & response quantity & & 3 & 57 & 120 & 57 & $\overline{9}$ \\
\hline OLOnator & percent $(\%)$ & & 0.7 & 13.8 & 29.1 & 13.8 & 2.2 \\
\hline interior & response quantity & & & 9 & 19 & 7 & 3 \\
\hline material & percent (\%) & & & 2.2 & 4.6 & 1.7 & 0.7 \\
\hline air nurifier & response quantity & & & & 149 & 89 & 14 \\
\hline & percent $(\%)$ & & & & 36.2 & 21.6 & 3.4 \\
\hline ventfan & response quantity & & & & & 189 & 50 \\
\hline & percent (\%) & & & & & 45.9 & 12.1 \\
\hline fragrance & response quantity & & & & & & 16 \\
\hline & response quantity & & & & & & \\
\hline other & percent (\%) & & & & & & \\
\hline
\end{tabular}

\section{3 換気調節}

換気調節に関しては筆者らによる既往報告 ${ }^{15)}$ で地域別特性など詳 しく説明しているが、本項では全国平均としてその内容の一部を簡単 にまとめた。

換気管理基準を設けている施設は夏期の居室 32\%、共用室 30\%、 冬期の居室 38\%、共用室 $36 \%$ と温度基準（順に 62\%、63\%、62\%、 64\%）より低く、空気污染と空気感染が発生しやすい冬場が若干高か った。換気管理基準の有無とは別に換気の調整をどのように行ってい るかについて、居室において「規則的に換気を行っている」と答えた

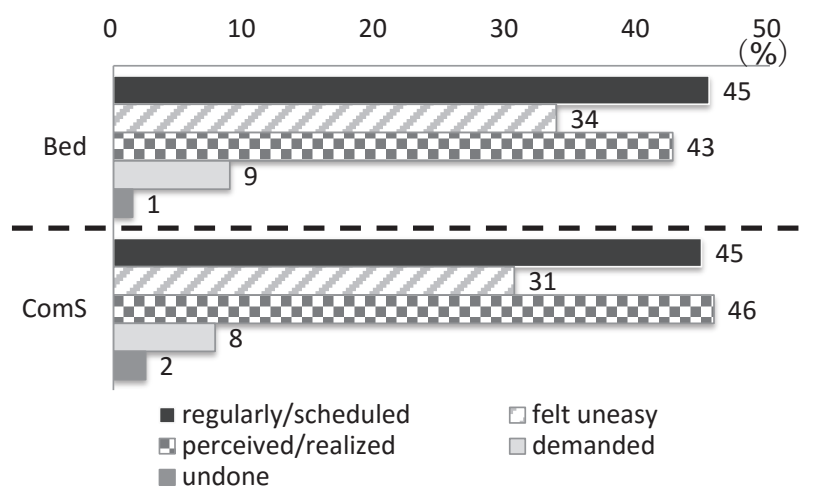

Fig. 5 Criteria for ventilation control 
施設は $45 \%$ と、「気になった時や気づいた時に行う」から重複を除い た 58\%より少なく、においや温度上昇など空気環境の悪化を認識し てからの対処が多いことが示された。「要望があった時」は $9 \%$ 、「特 にしていない」は1\%程度あった。

\section{4 知覚空気質}

Table3 に知覚空気質の申告結果をまとめた。質問対象は施設管理者 や担当者であり、場所を特定せず普段施設内で感じている印象につい て設問した結果である。臭気強度 (Odour intensity) としては「弱い (weak)」・「明確に分かる (distinct)」が約 8 割、「強い (strong)」・「と ても強い (very strong)」が 1 割で、平均としては臭気強度 2.5 と「弱 いと明確に分かるの中間程度」だったが、快不快度 (Hedonic tone) では約 8 割が不快側「やや不快 (modrately unpleasant)」51\%、「不快 (unpleasant)」24\%、「かなり不快（very unpleasant）」5\%の申告をし た。一方、受容度 (A cceptability) では「どちらでもない (neutral)」 が 46\%、「受け入れられる (acceptable)」が $29 \%$ と全体の $75 \%$ が中立 や肯定の回答をした。施設内の糞便臭・体臭が不快臭の原因であるこ とは明白であるが、施設用途の特性上やむを得ないという当然さが受 け入れられている結果と言える。

また、Table4 に知覚空気質間の相関分析結果を示す。 $\mathrm{R}$ は相関係数 (correlation coefficient)、a は回帰式の傾き（slope）である。臭気強 度に対して快不快度、受容度ともに有意な中程度の相関 $(0.4<|R|<$ 0.7）が認められた。

Table 3 Questionnaire result for odour perceptions

\begin{tabular}{|c|c|c|}
\hline Hedonic tone & Scale & Ratio (\%) \\
\hline extreamely unpleasant & -4 & 0.7 \\
\hline very unpleasant & -3 & 5.4 \\
\hline unpleasant & -2 & 23.5 \\
\hline moderately unpleasant & -1 & 50.5 \\
\hline neutral & 0 & 14.5 \\
\hline moderately pleasant & 1 & 1.9 \\
\hline pleasant & 2 & 2.2 \\
\hline very pleasant & 3 & 1.0 \\
\hline extremely pleasant & 4 & 0.3 \\
\hline \multicolumn{3}{|c|}{ M ean : -1.06 / S.D. : $1.08 \quad(n=592)$} \\
\hline Odour intensity & Scale & Ratio (\%) \\
\hline extremely strong & 6 & 0.7 \\
\hline very strong & 5 & 1.7 \\
\hline strong & 4 & 8.8 \\
\hline distinct & 3 & 43.6 \\
\hline weak & 2 & 33.1 \\
\hline very weak & 1 & 9.0 \\
\hline no odour & 0 & 3.2 \\
\hline \multicolumn{3}{|c|}{ Mean : 2.54 / S.D. : $0.99 \quad(n=592)$} \\
\hline Acceptability & Scale & Ratio (\%) \\
\hline unacceptable & -1 & 25.2 \\
\hline netural & 0 & 45.8 \\
\hline acceptable & 1 & 29.1 \\
\hline
\end{tabular}

Table 4 Correaltion analysis for odour perceptions

(R: correlation coefficient, a : slope in single regression)

\begin{tabular}{|c|c|c|c|c|c|c|}
\hline & \multicolumn{2}{|c|}{ Hedonic tone } & \multicolumn{2}{|c|}{ Odour Intensity } & \multicolumn{2}{|c|}{ Acceptability } \\
\hline & $|\mathrm{R}|$ & a & $|\mathrm{R}|$ & a & $|\mathrm{R}|$ & $\mathrm{a}$ \\
\hline Hedonic tone & & & $0.6455 * * *$ & -0.593 & $0.4029 * * *$ & 0.300 \\
\hline Odour Intensity & $0.6455^{* * *}$ & -0.703 & & & $0.4435 * * *$ & -0.295 \\
\hline Acceptability & $0.4029 * * *$ & 0.656 & $0.4435 * * *$ & -0.550 & & \\
\hline
\end{tabular}

\section{4. におい環境への影響因子}

以上の結果を基に二変量解析を行い相関を調べた。更に、分析結果 から臭気環境に影響を与える主要因子を抽出して多変量解析を実施 した。二変量解析の結果を Table5 に示す。

快不快度に関して、有意さが認められたのは 19 項目あったが、そ の中で「糞便臭」、においが気になる場所_居室（以下、場所_居室）」 が弱い相関 $(0.2<|R|<0.4)$ を、また「においが気になる場所_無い（以 下、場所_無い)」が中程度の相関 $(0.4<|\mathrm{R}|<0.7)$ を示した。

臭気強度に関しては、18 項目に有意さが認められたが、快不快度 と同様に「糞便臭」、「場所_居室」が弱い相関を、「場所_無い」が中 程度の相関を示した。受容度に関しては、11 項目に有意さが認めら れ、その中で「場所_無い」のみ弱い相関を示した。

「糞便臭」及び「場所_居室」は快不快度及び受容度と負の相関を 示すのに対し、臭気強度には正の相関を、一方「場所_無い」は各知 覚空気質項目に対して逆の相関を示す。

\section{5. 知覚空気質に関する多变量解析}

前述した二変量解析結果から知覚空気質に有意な相関があった説 明変数を抽出し多変量解析を行った。基本的にはステップワイズ法を 用いるが統計ソフトの自動機能ではなく、解析結果を確認し変数を選 別しながら段階解析を行った。

また、多変量解析におけるパラメータ推定は説明変数の尺度に大き く依存する。ここでは、複数説明変数による推定において各変数のス ケールに影響されず（scale-invariant）、効果の大きさ (effect size) を 見るため、尺度化した推定值 (scaled estimate) による検定を行った。 尺度化した推定值は平均を 0 、範囲を 2 に尺度化した要因に対する係 数である。

「5.1」節では二変量解析から有意さが認められた項目を下記(1)か ら(7)の分類にし、快不快度 - 臭気強度 ・受容度に対する多変量解析を 行った。

(1)建築・施設概要
(2)冷房・暖房・換気方式
(3)気になるにおい
(4)においが気になる場所

(5)換気管理基準有無・衛生管理の業務委託

(6)換気調整・省エネ

(7)におい対策

「5.2」節では以下に示す建築的要素及び行動的要素と、より大き な区分にして多変量解析を行い、有意性及び相関が認められる項目を 抽出した。

1) 建築・施設概要、設備（1)、(2)

2) 気になるにおいの種類・においが気になる場所（3)、(4)

3）管理基準・委託、換気調整・省エネ、におい対策（5)、(6)、(7)

更に、「5.3」節では全ての説明変数の中から知覚空気質に対する有 意さが認められ、寄与度の高い項目を抽出して回帰分析を行った。

\section{1 項目別の多変量解析}

(1)建築・施設関連項目からは「施設タイプ（従来型、併設型、ユニ ットケア型)」のみと有意な相関があり、他の変数との相関は認めら れなかった。 
Table 5 Bivariate analysis between odour perceptions and factors of facility and indoor environments $(* \mathrm{p}<0.05 、 * * \mathrm{p}<0.01, * * * \mathrm{p}<0.001, \mathrm{R}$ : correlation coefficient, a : slope in single regression)

\begin{tabular}{|c|c|c|c|c|c|c|c|c|}
\hline & \multicolumn{2}{|c|}{ hedonic tone } & \multicolumn{2}{|c|}{ odour intensity } & \multicolumn{2}{|c|}{ acceptability } \\
\hline & & & $|\mathrm{R}|$ & $a$ & $|\mathrm{R}|$ & $a$ & $|\mathrm{R}|$ & $a$ \\
\hline \multirow{6}{*}{$\begin{array}{c}\text { facility outline } \\
\text { (建築·施設概要） }\end{array}$} & region & 地域区分 & $<0.01$ & -0.0008 & 0.058 & -0.0644 & $<0.01$ & 0.0006 \\
\hline & structure & 建て方 & 0.048 & 0.1214 & $<0.01$ & -0.0002 & 0.014 & 0.0244 \\
\hline & number of floors & フロア数 & $<0.01$ & -0.0090 & 0.004 & -0.0043 & $<0.01$ & -0.0356 \\
\hline & gross floor area & 延べ床面積 & $<0.01$ & 0.0025 & $<0.01$ & -0.0047 & 0.041 & -0.0300 \\
\hline & nursing care type & 施設タイプ & $0.118 * *$ & 0.1535 & $0.110 * *$ & -0.1338 & $<0.01$ & 0.0031 \\
\hline & building age & 築年数 & 0.041 & -0.0045 & $0.105 \quad * *$ & 0.0107 & $<0.01$ & 0.0005 \\
\hline \multirow{2}{*}{$\begin{array}{l}\text { cooling equipment } \\
\text { (冷房方式) }\end{array}$} & bedroom & 居室 & 0.020 & -0.0388 & 0.039 & -0.0731 & 0.014 & -0.0197 \\
\hline & common space & 共用室 & 0.044 & -0.0834 & 0.014 & 0.0236 & 0.073 & -0.0951 \\
\hline \multirow{2}{*}{$\begin{array}{l}\text { heating equipment } \\
\text { (暖房方式) }\end{array}$} & bedroom & 居室 & 0.024 & -0.0546 & $<0.01$ & 0.0186 & 0.028 & -0.0426 \\
\hline & common space & 共用室 & 0.057 & -0.1260 & 0.052 & 0.1044 & 0.092 & -0.1369 \\
\hline \multirow{2}{*}{$\begin{array}{l}\text { ventilation } \\
\text { equipment }\end{array}$} & bedroom & 居室 & $0.111 * *$ & 0.1482 & 0.077 & -0.0952 & 0.047 & 0.0428 \\
\hline & common space & 共用室 & $0.111 \quad * *$ & 0.1402 & $0.097 *$ & -0.1143 & 0.020 & 0.0171 \\
\hline \multirow{4}{*}{$\begin{array}{l}\text { unpleasant odours } \\
\text { (気になるにおい) }\end{array}$} & feces & 糞便 & $0.263 * * *$ & -0.6102 & $0.290 * * *$ & 0.6223 & $0.196^{* * *}$ & -0.3107 \\
\hline & urine & 尿 & $0.100 \quad *$ & -0.3228 & 0.063 & 0.1902 & $0.102 *$ & -0.2258 \\
\hline & food & 食事 & 0.020 & -0.0911 & 0.014 & 0.0605 & $<0.01$ & 0.0299 \\
\hline & body & 体臭 & $0.089 *$ & -0.2912 & 0.093 & 0.2824 & 0.037 & -0.0829 \\
\hline \multirow{6}{*}{$\begin{array}{l}\text { odorous places } \\
\text { (においが気によなる場 } \\
\text { 所） }\end{array}$} & none & 無い & $0.401 * * *$ & 1.0824 & $0.405 * * *$ & -1.0131 & $0.215 * * *$ & 0.3920 \\
\hline & bedroom & 居室 & $0.256 * * *$ & -0.5540 & $0.283 * * *$ & 0.5675 & $0.156 * * *$ & -0.2304 \\
\hline & common space & 共用室 & 0.062 & -0.1789 & $0.134 * * *$ & 0.3560 & 0.028 & -0.0564 \\
\hline & corridor & 廊下 & $0.147 * * *$ & -0.3591 & $0.168 * * *$ & 0.3822 & 0.120 & -0.2001 \\
\hline & toilet & トイレ & $0.094 \quad * *$ & -0.2792 & 0.073 & 0.2005 & 0.047 & -0.0956 \\
\hline & other & その他 & $0.131 \quad * *$ & -0.3069 & 0.073 & 0.1584 & 0.053 & -0.0850 \\
\hline \multirow{4}{*}{$\begin{array}{c}\text { ventilation criteria } \\
\text { (換気管理基準) }\end{array}$} & summer_bed & 夏季_居室 & 0.099 & 0.2293 & 0.042 & -0.0901 & 0.040 & -0.0633 \\
\hline & summer_ComS & 夏季_共用室 & 0.071 & 0.1691 & 0.032 & -0.0675 & 0.040 & -0.0638 \\
\hline & winter_bed & 冬季_居室 & 0.071 & 0.1576 & 0.014 & -0.0269 & 0.098 & -0.1491 \\
\hline & winter_ComS & 冬季_共用室 & 0.085 & 0.1930 & 0.033 & -0.0679 & 0.079 & -0.0123 \\
\hline \multicolumn{3}{|c|}{$\begin{array}{c}\text { hygiene management comission } \\
\text { (none, demanded, regularly, resident) } \\
\text { (衛生管理委託一無し、必要時、定期巡回、常駐） }\end{array}$} & 0.103 & 0.1315 & 0.114 & -0.1376 & 0.036 & 0.0326 \\
\hline \multicolumn{3}{|c|}{$\begin{array}{c}\text { person for hygiene management } \\
\text { (none, concurrent, regular) } \\
\text { (衛生管理担当者一無し、兼任、専任) }\end{array}$} & 0.077 & 0.0876 & 0.015 & -0.0158 & 0.016 & 0.0132 \\
\hline \multirow{2}{*}{$\begin{array}{c}\text { energy saving } \\
\text { (省エネ) }\end{array}$} & cooling / heating & 冷暖房調節 & 0.085 & 0.2334 & 0.042 & -0.1092 & 0.077 & 0.1451 \\
\hline & ventilation & 換気量調節 & 0.062 & 0.1358 & 0.026 & -0.0568 & 0.022 & 0.0360 \\
\hline \multirow{6}{*}{$\begin{array}{l}\text { ventilation control } \\
\text { (換気調整) }\end{array}$} & regularly / scheduled & 定期的 & 0.065 & 0.1409 & 0.022 & -0.0460 & 0.026 & -0.0383 \\
\hline & felt uneasy & 気になつた時 & 0.077 & -0.1751 & 0.121 & 0.2537 & 0.070 & -0.1080 \\
\hline & percieved / realized & 気づいた時 & 0.010 & -0.0257 & 0.042 & -0.0869 & 0.058 & 0.0867 \\
\hline & demanded & 要望時 & 0.010 & 0.0459 & 0.050 & 0.1741 & 0.017 & 0.0411 \\
\hline & none & 無い & 0.028 & 0.2458 & 0.024 & -0.1963 & 0.010 & -0.0451 \\
\hline & combined & 複数調整 & 0.010 & -0.0174 & 0.059 & 0.0882 & 0.020 & -0.0210 \\
\hline \multirow{8}{*}{$\begin{array}{l}\text { odour related } \\
\text { measures_Bed } \\
\text { (におい対策_ } \\
\text { 居室) }\end{array}$} & none & 無し & 0.061 & 0.4053 & 0.096 & -0.5989 & 0.096 & 0.4353 \\
\hline & Ozonator & オゾン & 0.014 & 0.0357 & 0.026 & -0.0640 & 0.048 & 0.0849 \\
\hline & interior material & 建材 & 0.039 & 0.2163 & 0.047 & -0.2474 & $<0.01$ & 0.0030 \\
\hline & air purifier & 空気清浄機 & 0.039 & -0.0954 & 0.033 & 0.0768 & 0.071 & -0.1186 \\
\hline & vent fan & 換気扇 & $0.106 \quad * *$ & -0.2572 & $0.092 *$ & 0.2062 & $<0.01$ & 0.0024 \\
\hline & fragrance / deodorant & 芳香·防臭剂 & $0.118 \quad * *$ & -0.2540 & $0.148^{* * *}$ & 0.2953 & 0.056 & -0.0820 \\
\hline & other & その他 & 0.014 & 0.0469 & 0.041 & 0.1282 & $0.110 * *$ & -0.2506 \\
\hline & combined & 複数 & $0.119 * *$ & -0.1402 & $0.132 * *$ & 0.1466 & 0.080 & -0.0647 \\
\hline \multirow{8}{*}{$\begin{array}{l}\text { odour related } \\
\text { measures_ComS } \\
\text { (におい対策_- } \\
\text { 共用室) }\end{array}$} & none & 無し & $<0.01$ & -0.0111 & 0.052 & -0.3052 & 0.052 & 0.2142 \\
\hline & Ozonator & オゾン & 0.010 & 0.0265 & 0.028 & -0.0627 & 0.046 & 0.0762 \\
\hline & interior material & 建材 & 0.076 & 0.4284 & 0.040 & -0.2903 & 0.014 & 0.0509 \\
\hline & air purifier & 空気清浄機 & 0.022 & 0.0541 & 0.119 & 0.0852 & 0.022 & -0.0346 \\
\hline & vent fan & 換気扇 & $0.120 \quad * *$ & -0.2814 & $0.040 * *$ & 0.2594 & 0.017 & -0.0292 \\
\hline & fragrance / deodorant & 芳香·防臭剂 & 0.033 & -0.0760 & $0.104 *$ & 0.2177 & 0.017 & -0.0271 \\
\hline & other & その他 & $<0.01$ & 0.0249 & 0.033 & 0.1089 & $0.091 *$ & -0.2132 \\
\hline & combined & 複数 & 0.036 & -0.0433 & $0.113 * *$ & 0.1236 & 0.046 & -0.0370 \\
\hline
\end{tabular}


(2)冷房・暖房・換気設備では快不快度及び臬気強度に対して「換気 設備方式（無し、換気扇、ハイブリッド式、中央式）」のみ説明変数 として有意であり、二変量解析と類似した結果となった。

(3)快不快度に対しては「糞便臭」、「尿臭」及び「体臭」に有意さが 認められた。臭気強度については「粪便臭」と「体臭」の 2 項目、受 容度について有意さが認められた項目も「粪便臭」と「尿臭」であっ た。

(4)においが気になる場所は、全体的には「場所_無い」と答えた施 設は快適度及び受容度が高く、臭気強度は低下している。においがす る場所が有ると答えた施設は逆の傾向を示している。快適度について 有意さが認められた項目は、「場所_無し、居室、廊下、トイレ、その 他」であり、臭気強度については「無し、居室、共用室、廊下」で有 意さが認められた。受容度については「無し、居室、廊下」で有意さ が認められた。

しかしながら、「場所無い」は知覚空気質 3 項目に対して影響度が 最も大きい一方、におい環境を肯定側に評価させ他の要素とは逆相関 を示すことから、多変量解析では本項目は同じ評価要素として用いる ことが出来ないと判断された。以降の多変量解析結果では「場所_無 い」を除いた結果について報告する。

(5)換気管理基準及び衛生管理基準項目から相関が得られたものは、 快不快度と「換気管理基準_夏期の居室」及び「衛生管理基準」であ り、臭気強度及び受容度に対して説明可能な变数は衛生管理基準のみ であった。

(6)換気調整では知覚空気質の多変数による説明は出来なかった。

(7)居室のにおい対策と知覚空気質の関係からは、「換気扇」及び「芳 香・防臭剤」の使用が快不快度及び臭気強度に対して有意な相関を示 し、この $2 つ の$ 変数による説明が可能であった。一方、受容度に対し ては「その他」のみ有意な相関があり、多変数による説明はできなか った。

共用室のにおい対策と知覚空気質の関係からは、「建材」と「換気 扇」が快不快度に対して働いているが、「換気扇」が不快度を増すこ とに対して「建材」は快適度を増加させる働きをしている。また、両 変数は臭気強度についても居室と同様の結果を示す。

\section{2 建築的要素と行動的要素による多変量解析}

建築的要素と行動的要素別に 1)「(1)、(2)」、2)「(3)、(4)」、3)「(5)、 (6)、7」に区分して行った多変量解析からは以下の結果が得られた。

1) 建築・施設・設備の要素で快不快度に対して最も相関がある変 数としては、「施設タイプ」と「居室の換気方式」であった。一方、 臭気強度に対して最も相関がある变数は、「施設タイプ」と「共用室 の換気方式」であった。受容度に関しては「暖房方式」が有意であり 他の因子は認められなかった。

2)においの種類とにおいがする場所から見ると、「糞便臭、尿臭」、 「居室、廊下、その他」の場所が快不快度の影響因子として抽出され たが、臭気強度に関しては「資便臭、場所_居室、場所_廊下」のみが 選定された。快不快度、臭気強度ともに「臯便臭＞場所_居室＞場所_ 廊下」の順に不快度及び臭気強度の増加に寄与していた。同じ变数を 用いて受容度に関しても解析を行ったが、「糞便臭」及び「場所_居室」 は説明変数として有意であったが、「場所_廊下」からは有意な相関が 見られなかった。

3）人間の行動によるにおい対策からは、「対策_居室の換気扇、対

策_居室の芳香・防臭剤」が快不快度に有意な相関が認められた。に おい対策行動と臭気強度及び受容度に関する分析から有意な結果は 得られなかった。

\section{3 全説明変数からの多変量解析}

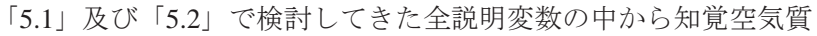
に対する有意さが認められ、寄与度の高い項目を抽出して重回帰分析 を行った結果をFig.6に示す。但し、前述した通り「場所_無い」は 影響度が最も大きい一方、他の要素とは逆相関を示すことから、本項 目は除いた結果となる。結果、快不快度に関しては「施設タイプ、場 所_居室、翼便臭、対策_居室の換気扇」の 4 つが説明変数として挙げ られた。寄与度が大きな順から「翼便臭＞場所_居室＞施設タイプ> 対策_居室の換気扇」となった。

臭気強度に関しては上記 4 項目中「対策_居室の換気扇」が脱落し、 結果「粪便臭＞場所_居室＞施設タイプ」の順に影響度が高かった。

受容度は 4 項目中「対策_居室の換気扇、施設タイプ」の 2 項目が 脱落し、「臯便臭＞場所_居室」と 2 項目の夕有意な相関を持つことが 明らかとなった。

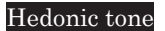

\section{intercept facility type \\ odour feces place_bedroom measures_vent_bed}

\section{Odour intensity}

intercept

facility type

odour feces

place_bedroom

measures_vent_bed
Scaled Estimate

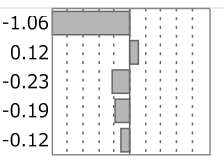

Scaled Estimate

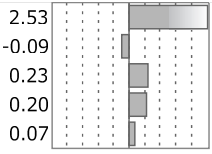

Acceptability

intercept

facility type

odour_feces

place_bedroom

measures_vent_bed

※ scaled estimate
Std Error t Ratio p Value

$\begin{array}{rrr}0.042 & -25.1 & <.0001 * \\ 0.052 & 2.4 & 0.0184 * \\ 0.048 & -4.7 & <.0001 * \\ 0.044 & -4.2 & <.0001 *\end{array}$

$\begin{array}{lll}0.047 & -2.5 & 0.0117^{*}\end{array}$

Std Error t Ratio p Value

$\begin{array}{lll}0.038 & 66.4 & <.0001 *\end{array}$

$0.047 \quad-2.0 \quad 0.0456 *$

$0.044 \quad 5.2<.0001 *$

$0.040-5.0<<.0001 *$

$0.043 \quad 1.7 \quad 0.0983$

Std Error t Ratio p Value

\begin{tabular}{|c|c|c|c|}
\hline 0.04 & 0.030 & 1.3 & 0.1799 \\
\hline-0.01 & 0.036 & -0.3 & 0.7670 \\
\hline-0.13 & 0.034 & -3.7 & $0.0002 *$ \\
\hline-0.08 & 0.031 & -2.6 & $0.0104 *$ \\
\hline 0.03 & 0.033 & 1.0 & 0.3110 \\
\hline
\end{tabular}

centered by mean, scaled by range / 2

Fig. 6 Multivariate analysis by human behaviors and architectural factors

以上の結果から、知覚空気質「快不快度、臭気強度、受容度」を同 時に説明できる項目は「糞便臭＞場所_居室」であり、その回帰分析 の結果はFig.7 の通りである。

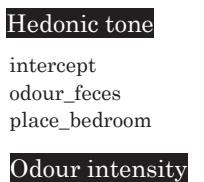

intercept

odour feces

place_bedroom

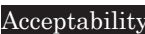

intercept

odour_feces

place_bedroom

※ scaled estimate

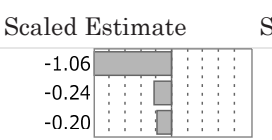

Std Error t Ratio p Value $0.042-24.9<.0001 *$ $0.048 \quad-5.0 \quad<.0001^{*}$ $0.045 \quad-4.4<.0001 *$

Scaled Estimate Std Error t Ratio p Value $\begin{array}{c:c:cccc}2.54 & & 0.038 & 66.3 & <.0001^{*}\end{array}$ $\begin{array}{lllll:llll}0.23 & & & 0 & & 0.043 & 0.4 & <.0001^{*}\end{array}$ $\begin{array}{ll:ll:llll}0.21 & & 0 & 0.040 & 5.2 & 0.0001^{*}\end{array}$

Scaled Estimate Std Error t Ratio p Value

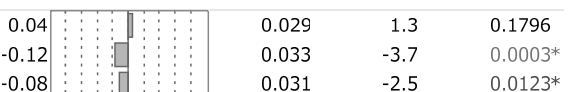

Fig. 7 Multivariate analysis by all explanatory variables 


\section{6. 考察}

高齢者施設ではオムツ換え、排泄介助などが必要な要介護度が高い 利用者が多く、トイレ・污物処理室よりも居室・廊下など日常生活を 送っている空間における翼尿臭や体臭が問題となっていた。

対策（Fig.4）として換気扇をメインに空気清浄機、オゾン発生器 などの機器を用いている施設も多かったが、これら機器の居室での利 用率は共用室より低く、居室には芳香・防臭剂等を置いている施設が 半数近くあった。におい対策のための機器と用品の併用率も高く、に おいが大きな問題になっていることは明らかである。

においが不快であることを認識しているものの、中立・受け入れら れるとの回答が多く (Table3)、施設特性上やむを得ないと我慢して いることがうかがわれ、より快適な入所生活・勤務環境を創るために もにおいへの配慮は重要と言える。

Table5 の二变量解析結果からは、換気扇や芳香・防臭剤は不快度を 増加させる因子として働くのではなく、普段におい環境が悪い施設ほ どこの類のにおい対策を取っていることを示していると解釈する方 が妥当と言える。臭気強度についても同様の解釈ができる。

Table5 の二変量解析から、快不快度に対して有意さが認められた説 明変数は 19 項目、臭気強度では 18 項目、受容度では 11 項目あった。 快不快度と臭気強度に相関が認められたのは「糞便臭」「場所_居室」、 「場所_無い、受容度に関しては「場所_無い」が相関関係を示した。 「糞便臭」及び「場所_居室」は快不快度と受容度と負の相関を示す のに対し、臭気強度には正の相関を示す。一方、「場所_無い」はそれ らとは逆の相関を示した。「場所_無い」は知覚空気質 3 要素に対して 影響度が大きく、知覚空気質の善し悪しを説明する上で他の因子の影 響を逆方向の評価に相殺するため多变量解析で他の説明変数と同時 に解析を行うことは出来ない。

「場所_無い」を除いた多変量回帰分析から、知覚空気質（快不快 度・臭気強度・受容度) に対して説明可能な候補として「施設タイプ、 場所_居室、糞便臭、対策_居室の換気扇」の 4 つの変数が抽出され、 最終的に知覚空気質を全て説明できる变数は「気になるにおい臯便 臭」、「においが気になる場所_居室」の 2 項目であることが明らかに なった。影響度は「粪便臭>場所_居室」となり、粪便臭が最も重要 な因子となるが、特養では居室のにおいも大きな問題になっているこ とが明らかになった。

\section{7. 結論}

高齢者施設におけるにおいは施設関係者や利用者にとっても不快 感を引き起こす悩ましい問題であり、様々なにおい対策が講じられて いる。しかし、職員や施設関係者はにおいが不快と感じながらも施設 特性上、我慢して耐えている現状がうかがわれた。

施設内の臭気強度が高くなると、快不快度は不快側に、受容度は受 け入れられない側に評価が下がる相関が調査結果からも得られた。知 覚空気質（快不快度・臭気強度・受容度）を目的变数に行った二变量 解析から、快不快度に対して有意性が認められた説明変数は 19 項目、 臭気強度では 18 項目、受容度では 11 項目あった。結果的には、「気 になるにおいの種類」と「においが気になる場所」が知覚空気質に対 すル最も重要な説明因子となった。

「場所_無い」は他の説明変数より相関性も強く影響度が大きいが、 におい環境を肯定側に評価させ他の要素とは逆相関を示すことから、
多変量解析では「場所_無い」は同じ評価因子として用いることは出 来ないと判断された。即ち、においが気になる場所が「無い」は空気 環境をよく評価させる最も重要な要素として捉えることができ、不 快・非容認といった負の評価要素として用いる必要はないと言える。

「場所_無い」を除いた多変量解析からは、知覚空気質を説明可能 な候補として「施設タイプ、場所_居室、粪便臭、対策_居室_換気扇」 の 4 つの変数が抽出されたが、知覚空気質 3 項目全てを説明できる変 数は「糞便臭」、場所_居室」の 2 つであった。影響度としては「臯 便臭＞場所_居室」であり、においの種類としては瓷便臭が最も重要 な因子となるが、特養では居室のにおいが大きな問題になっているこ とが明らかになった。

室内空気質の改善対策としては、発生源・換気・除去対策の 3 づ 挙げられるが、高齢者施設では発生源が最も重要で影響度が高く、換 気や除去対策では十分に対応しきれない現状がうかがわれた。

発生源対策と共に空気環境改善の根幹と言える換気においては、施 設の半数以上が規則的な換気を行うのではなく、においや温度上昇な ど空気環境の悪化を認識してから対処していることが示された。特に 換気はにおいだけでなく温湿度、快適感、空気感染の防止などに役立 つ対策であり、施設に対する換気の励行と教育は重要な課題である。 本研究では高齢者施設のにおい環境には換気より発生源対策が より影響度が高いことを示したが、においは換気を行うための感覚的 な指標にもなるため、におい環境改善は換気環境の改善、ひいては空 気環境全般の改善につながる。高齢者福祉施設では施設の特性上、八 イリスクアプローチが重視されているが、におい環境の改善はサービ ス従事者の業務環境の改善のみならず、換気や空気質と密接に関わる ため入所者の健康リスク低減の面からも重要な評価要素となる。今後 さらに臭気強度などの定量測定など実態を検証し、室内環境の改善に 向けて提案を行っていく必要がある。

本研究は「国立保健医療科学院基盤的研究費」による研究（倫理審査 承認番号 NIPH-TRN\#12016）成果の一部である。

注

注 1) 標本数を決定するために、以下の公式を用いた。 $\mathrm{n}=\mathrm{N} /\left[(\varepsilon / \mathrm{K}(\alpha))^{2} \times\{(\mathrm{N}-1) / \mathrm{P}(1-\mathrm{P})+1\}\right]$

$\mathrm{n}:$ 必要とされる標本数

$\mathrm{N}$ : 母集団の大きさ

$\varepsilon$ : 区間推定で標本特性値につける土の幅

$\alpha$ : 母集団特性值の推定を誤る確率（\%)

K $(\alpha)$ : 正規分布の性質から決められる値。信頼度 $95 \%$ の時は 1.96

$\mathrm{P}:$ 母比率 $(\%)$

$\mathrm{N}=5878 、 \varepsilon=3(\%) 、$ 信頼度 $95 \%$ とし、 $\mathrm{P}=50 \%$ と仮定すると、 $\mathrm{n}=748.7$ となる。7 767 票の有効回答数はこの数字を上回っており、必要標本数は確 保できたと判断した。

注 2) 2016 年 5 月現在、省エネルギー法の改正に伴い、地域区分もより細かい 8 区分となったが、母数に限界があるため細か寸ぎる地域区分を採用するの は難しく、また既報との整合を合わせるために次世代省エネ基準（H11 年 度）による旧地域区分 6 区分を用いた。

注 3）VI 地域は回答数 4 件と統計的な意味をなさないが、他地域と区別できる 特徴を呈していることもあるため、本論文では参考值として用いている。

注 4) 本研究は統計学でよく用いる以下のギルフォード基準 (Guilford's Rule of Thumb）を相関の判断として適用した。

$|r|=0.7 \sim 1 \quad$ かなり強い相関がある

$|r|=0.4 \sim 0.7 \quad$ 中程度の相関あり

$|r|=0.2 \sim 0.4 \quad$ 弱い相関あり

$|r|=0 \sim 0.2$ ほとんど相関なし 
参 考 文 献

1) Health, Labour and Welfare Ministry : The white paper 2016 Shiryouhen demographic structure, changes in population in Japan -,

http : //www.mhlw.go.jp/wp/hakusyo/kousei/16-2/dl/00.pdf, (accessed 2017.6.24)

(In J apanese)

厚生労働省, 平成 28 年版厚生労働白書 資料編一人口構造, 我が国の人口 の推移 - (accessed 2017.6.24)

2) M inistry of Internal Affairs and Communications: The 2010 Population Censes -basic calculation result, Table 6-

http://www.stat.go.jp/data/kokusei/2010/kihon1/pdf/gaiyou1.pdf, http://www.e-stat.go.jp/SG1/estat/N ewL ist.do?tid=000001039448

(accessed 2016.9.20) (In J apanese)

総務省，平成 22 年国勢調査一人口等基本集計結果一，一人口等基本集計

(男女・年齢・配偶関係，世帯の構成，住居の状態など)第 6 表一

(accessed 2016.9.20)

3) Hisano, S. et al. : Finding a physical environment desirable for elderly residential facilities : A survey of the literature, Journal of health sciences, Hiroshima U niversity, Vol. 3(1), pp. 21-36, 2003.11. (In J apanese)

久野真矢，清水一：文献調査から見出した高齢者施設の好ましい物理的 環境，広島大学保健学ジャーナル, Vol.3(1), pp. 21-36, 2003.11.

4) Yano, H. et al. : Current conditions and measures of winter infection of the elderly, Geriatric M edicine, 46 (11), pp.1337-1341, 2008.11. (In Japanese)

矢野久子，鈴木幹三：高齢者の冬季感染症の現状と対策一冬季における 高歯者の施設内感染症の現状と対策＼cjkstart高齢者施設と在宅領域の要介護高 齢者への感染予防, Geriatric M edicine, 46 (11），pp.1337-41, 2008.11.

5) Inamatsu, T. : M easures against infectious diseases in facilities for the elderly, INFECTION CONTROL, 15(11), pp. 1080-1083, 2006.11. (In J apanese) 稲松孝思：高齢者施設における感染症対策，INFECTION CONTROL, 15(11), pp. 1080-3, 2006.11.

6) M urata, J. et al. : The Home Care Situation for the Elderly and an Evaluation of Their Environment. Journal of Environmental Engineering (Transactions of AIJ), A rchitectural Institute of J apan, Vol.81, N 0.725, pp.599-606, 2016. (In J apanese) 村田順子，光田恵，板倉朋世，毛利志保，棚村壽三：在宅介護の実態と介 護環境の評価一在宅介護環境下におけるにおいに関する研究，日本建築学 会環境系論文集, Vol.81 N 0.725, pp.599-606, 2016.07.

7) Itakura, T. et al. : Characteristics of excretory odor in medical facilities : part 1-Sensation evaluation of excretory odor and odor component analysis, J ournal of J apan A ssociation on Odor Environment, pp.85-88, 2007.06. (In J apanese) 板倉朋世，光田恵，柴田英希，医療施設における排泄物のにおいの特性に 関する研究 第 1 報 排泄物の臭気感覚評価と臭気成分分析，第20回にお い・かおり環境学会, pp.85-88, 2007.06.

8) Mitsuda, $M$. et al. : Odor in elderly care environment, Journal of Japan A ssociation on Odor Environment : part 1-Survey on houses and facilities for the elderly, Proceedings of Japan Association on Odor Environment, pp.109-110, 2015.08. (In J apanese)

光田恵, 萬羽郁子, 板倉朋世, 都築和代, 棚村壽三, 山下千穂：高齢者の 介護環境におけるにおいに関する研究 第 1 報 住宅と高齢者施設におけ る調査，第 28 回におい.かおり環境学会, pp.109-110, 2015.08.

9) Aibu, H. et al. : Odor in elderly care environment, Journal of Japan A ssociation on Odor Environment : part 2- Investigation of odor source in residential care environment, Proceedings of Japan Association on Odor Environment, pp.111-112, 2015.08. (In J apanese)

相武広樹，光田恵，棚村壽三，可児歩夢，高齢者の介護環境におけるにお いに関する研究 第2 報 住宅介護環境における臭気源の調査, 第28回に おい・かおり環境学会, pp.111-112, 2015.08.

10) Kataoka, E. et al. : Development of Ventilation Control System Using Air Pollutant Sensors in Sickrooms Part2 : Design Brief and Investigation of Operation on Hospital Project that have Utilized the Ventilation control system, Technical papers of annual meeting, The Society of Heating, A ir-Conditioning Sanitary Engineers of Japan, pp.1547-1550, 2012.09 (In Japanese)

片岡えり，塚見史郎：空気污れセンサーを利用した病室換気量制御シス テムの開発（第 2 報）空気污れセンサーを利用した病室換気量制御システ ムを導入した病院の概要と運用実態, 空気調和・衛生工学会大会学術講演 論文集, pp.1547-1550, 2012.09.
11) Nishimura, N. et al. : A Study of a Method for Maintaining a Sanitary Environment at Welfare Facilities for the A ged : Part 1-Investigation and Results based on Legal Measurement, Transactions of the Society of Heating, Air-conditioning and Sanitary Engineers of Japan, 179, pp. 27-34, 2012.02. (In Japanese)

西村直也，鍵直樹，柳宇，池田耕一，吉野博，斉藤秀樹，斉藤敬子，鎌倉良 太，小烟美知夫：老人福祉施設における室内環境の衛生管理に関する研 究：第 1 報-建築物衛生法に基づく実測調査とその結果，空気調和・衛生 工学会論文集, 179, pp. 27-34, 2012.02.

12) Nishimura, N. et al. : A Study on the Way of Maintenance of Sanitary Environment in Welfare Facilities for the Elderly : Part 2 Results of Continuous M easurements and VOC M easurements, Transactions of the Society of Heating, Air-conditioning and Sanitary Engineers of Japan, 185, pp. 11-18, 2012.08. (In Japanese)

西村直也，柳宇，鍵直樹，池田耕一，吉野博，齊藤秀樹，齊藤敬子，鎌倉良 太，小畑美知夫：老人福祉施設における室内環境の衛生管理に関する研 究 一 第 2 報-連続測定の結果および VOC 類の測定結果, 空気調和・衛生 工学会論文集, 185, pp. 11-18, 2012.08.

13) $\mathrm{Kim}, \mathrm{H}$. et al. : M easurement of temperature, humidity and $\mathrm{CO} 2$ concentration and estimation on humidity control in facilities for the elderly in winter, Indoor Environment, Vol.18 (2), pp. 77-87, 2015.12. (In J apanese)

金勲，林基哉，開原典子，大澤元毅，阪東美智子：高齢者施設における冬 期の温度, 湿度, CO2 濃度の実測調査及び湿度管理に関寸る分析，室内環 境, Vol.18 (2), pp. 77-87, 2015.12.

14) Bando, M. et al. : Survey on indoor environment in nursing homes for the elderly, J ournal of the National Institute of Public Health, 63(4), pp.359-367, 2014.08. (In J apanese)

阪東美智子，金勲，大澤元毅：特別養護老人ホームにおける環境衛生管理 の現状と課題，保健医療科学，63(4), pp. 359-367, 2014.08.

15) KIM , H. et al. : M anagement Situation of Indoor Environment and HAV C System in Facilities for the Elderly. J ournal of Environmental Engineering (Transactions of AIJ), A rchitectural Institute of J apan, Vol.82, N o.736, pp.589-597, 2017.06. (In J apanese)

金勲，阪東美智子，大澤元毅，林基哉：高齢者施設の室内環境及び空調設 備の管理実態に関する全国調査，日本建築学会環境系論文集，Vol.82 N 0.736 , pp.589-597, 2017.06.

16) WELNESS : Secondary M edical Region Database system, Ver2.0.0.xls http://www.wellness.co.jp/siteoperation/msd/index.php?mode=download_do\&file =data_t (accessed 2013-11-08) (In J apanese)

WELNESS: 2 次医療圈データベースシステム 全国特別養護老人ホーム一 覧データ Ver2.0.0.xls. (accessed 2013-11-08)

17) Ministry of Economy, Trade and Industry, Ministry of Land, Infrastructure, Transport and Tourism : Criteria for judgment by Owners of the building and the specific building regarding rational use of energy, http://www.mlit.go.jp/common/001016464.pdf (accessed 2014.07.10) (In J apanese)

エネルギーの使用の合理化に関する建築主等及び特定建築物の所有者の 判断の基準 (平成 25 年経済産業省・国土交通省告示第 1 号) (accessed 2014.07.10) 


\title{
ODOUR ENVIRONMENT AND MANAGEMENT \\ IN FACILITIES FOR THE ELDERLY
}

\author{
Hoon KIM ${ }^{* 1}$, Michiko BANDO ${ }^{* 2}$, Motoya HAYASHI ${ }^{* 3}$ \\ and Haruki OSAWA *1

\footnotetext{
${ }^{* 2}$ Chief Senior Researcher, National Institute of Public Health, Dr.Eng:
} \\ ${ }^{* 1}$ Senior Researcher, National Institute of Public Health, Dr.Eng. \\ ${ }^{*}$ Research Managing Director, National Institute of Public Health, Dr.Eng.
}

It is critical to understand the facility managing system and the actual condition of indoor environment in order to improve quality of life such as health and comfort, and to prevent infectious diseases in care welfare facilities for the elderly. Although the related facilities are in high demand, the actual situation of indoor environment has not been clear since there have not been a regulation and control law at all. Moreover, there are many residents who need a high degree of nursing care in those facilities and inevitably odours arisen out of excretion help and human body have been a persistent problem.

The mid and long term goal of our research is to suggest the proper planning and operational management to improve the indoor air environment in those facilities. The field surveys and the questionnaire on special nursing homes all over the country have been conducted to clarify the actual condition and the maintenance of indoor environment such as temperature, humidity, air quality and ventilation situation.

In this study to clarify the odour environment and problems, the questionnaire items related to the odour environment were extracted and analyzed statistically.

The followings were reported in this article.

1) Questionnaire results on odour perceptions and measures for odour control

2) Bivariate analysis between odour perceptions and facility environmental / behavioral factors

3) Elucidation of influential factors on odour environment by multivariate analysis

As a result, it was obvious that the feces and body odour perceived at rooms and corridors were the major problem. Although a large majority of respondents reported the discomfort come from the feces odour, most of replies to acceptability were on neutral and acceptable side.

The facilities taking a measure for odour were likely to declare a higher degree of discomfort. It was reasonable, however, to interpret that the odour measures such as ventilation, fragrance and deodorant did not work as factors increasing the degree of discomfort, but rather that those were desired in the facilities with poor odour environment. The same explanation could also be made for odour intensity.

The bivariate analysis derived 19 variables as significant effect factors for hedonic tone, 18 variables for odour intensity and 11 variables for acceptability. Furthermore, the multivariate analysis derived the four factors of nursing care type, odorous bedroom, feces odour and ventilation by fan as the decisive candidates for perceived air quality. Conclusively feces odour and odorous bedroom were defined as the most decisive explanatory variables that could simultaneously explain all three objective variables of odour perceptions.

To control the odour environment indoor can lead to not only improving the working environment for staffs but also reducing the health risk of residents since it is also closely related to ventilation and general indoor air quality. 